not aware of evidence to show that prolongation of hospital stay in these patients will result in a lower mortality.

We have adopted a conservative attitude to the treatment of complete heart block and all patients were treated medically except for two who were paced electrically. Anterior infarction as a cause of heart block was associated with a higher mortality $(78 \%)$ than inferior infarction $(36 \%)$. These figures compare adequately with those of Lassers and Julian (1968) and of Scott et al. (1967) who paced much more frequently than we have done. We are not convinced, however, that our conservative approach is the correct one.

We conclude that a shorter period in hospital and more rapid mobilization than are normally practised are justified. By so doing beds in coronary care units are made available for patients who are at the highest risk within the first few hours and days after acute myocardial infarction.

We thank Mr. W. Deaville, Mr. John Silk, all the nursing staff on the coronary care unit, and Mrs. J. Christian, for their co-operation, Mrs. O. Adams and Mrs. I. Roscoe for secretarial help, Mrs. Leslie Barker of the Heart Research Fund of North Staffordshire for the purchase of monitoring and $x$-ray screening equipment, Dr. $M$. Kennedy and Dr. B. Cromie for much helpful advice, and Hoechst Pharmaceuticals for financial support.

We also thank the many senior house officers who have worked in the cardiac department for all the help they gave us, and Miss Julia $M$. Massey, of the computer department of the North Staffordshire Hospital Group, who kindly performed the statistical analysis.

\section{References}

Boyle, D. McC., Barber, J. M., Walsh, M. J., Shivalingappa, G., and Chaturvedi, N. C. (1972). Lancet, 2, 57.

Chapman, B. L. (1971). British Heart fournal, 33, 643.

Friedberg, C. K. (1966). Diseases of the Heart, 3rd edn., p. 892. Philadelphia, Saunders.

Gilchrist, I. C. (1971). British Medical fournal, 4, 153.

Groden, B. M. (1967). Scottish Medical fournal, 12, 297.

Lassers, B. W., and Julian, D. G. (1968). British Medical fournal, 2, 142.

Lown, B. (1969). Archiv für klinische Medizin, 216, 201.

Lown B. (1967). Journal of the American Medical Association, $199,188$.

the American Medical Association, 199, 188.
Lown, B. et al. (1967). American Yournal of Cardiology, 20, 494.

Marriott, H. J. L., and Fogg, E. (1970). Modern Concepts of Cardiovascular Disease, 39, 103

Maurer, B. J., Wray, R., and Shillingford, J. P. (1971). Lancet, 2, 1385.

Meurs, A. A. H., Vos, A. K., Verney, J. B., and Gerbrandy, J. (1970). British Heart fournal, 32, 232.

Murray, T. S., Lorimer, A. R., Cox, F. C., and Lawrie, T. D. V. (1970). Lancet, 2, 792.

Nagle, R., Gangola, R., and Picton-Robinson, I. (1971). Lancet, 2, 454.

Norris, R. M., Brandt, P. W. T., Caughey, D. E., Lee, A. J., and Scott, P. J. (1969). Lancet, 1, 274.

Pentecost, B. L., and Mayne, N. M. C. (1968). British Medical fournal, 1,

Price, F. W. (1946). Textbook of the Practice of Medicine, 7th edn., p. 1028. London, Oxford University Press.

Royston, G. R. (1972). British Heart fournal, 34, 526.

Schlichter, J., Hellerstein, H. K., and Katz, L. N. (1954). Medicine, 33, 43. Scott, M. E., Geddes, J. S., Patterson, G. C., Adgey, A. A. J., and Pantridge,

Smyllie, H. C., Taylor, M. P., and Cuninghame-Green, R. A. (1972). British Medical fournal, $1,34$.

Spiekerman, R. E., Brandenburg, J. T., Achor, R. W. P., and Edwards, J. E. (1962). Circulation, 25, 57

Thompson, P., and Sloman, G. (1971). British Medical fournal, 4, 136.

Wood, P. (1956). Diseases of the Heart and Circulation, 2nd edn., p. 750. London, Eyre and Spottiswoode.

\title{
Anti-oestrogen Therapy for Breast Cancer: A Trial of Tamoxifen at Two Dose Levels
}

\author{
H. W. C. WARD
}

British Medical fournal, 1973, 1, 13-14

\section{Summary}

Tamoxifen (ICI 46474) was given by mouth to patients with advanced, recurrent, or metastatic breast carcinoma. At a dosage of $10 \mathrm{mg}$ twice daily $60 \%$ of patients showed arrest or reversal of tumour growth. At a dosage of $20 \mathrm{mg}$ twice daily $77 \%$ showed arrest or reversal of tumour growth. Side effects were usually trivial and their incidence was the same at both dose levels. No patients showed virilization or fluid retention.

\section{Introduction}

Tamoxifen is the trans-isomer of 1 (p- $\beta$-dimethylaminoethoxyphenyl)-1, 2-diphenylbut-1-ene. In several but not all mammalian species it is a potent anti-oestrogen. It is thought to act by blocking oestrogen receptors. Nevertheless, very high dosage in rats has an oestrogenic effect while low dosage is antioestrogenic. The first clinical use of an anti-oestrogen for breast carcinoma was described by Kistner and Smith (1960) and further trials were described by Herbst et al. (1964). The only published report on the use of tamoxifen is that of Cole et al. (1971).

Department of Radiotherapy, Queen Elizabeth Hospital, Birmingham B15 2TH

H. W. C. WARD, M.R.C.P., F.F.R., Consultant Radiotherapist

\section{Patients and Methods}

Sixty-eight patients were admitted to the trial. They all had either very advanced primary carcinoma of the breast, recurrence on the chest wall, or soft tissue metastases which could be measured. Other metastases might have been present but these did not affect admission to the trial. In most patients a histological diagnosis was available but in a few patients with very advanced primary disease a biopsy specimen had not been obtained. No patient was admitted to the trial unless there had been a lapse of at least three months from previous treatment with hormones or cytotoxic drugs and from the menopause, either natural or artificial.

Patients were divided into four groups depending on the presence or absence of blood-borne metastases and whether more or less than five years had elapsed from the menopause. For each group a previously prepared randomization table was used to allocate a patient to low or high dose treatment so that the number receiving low or high dosage in each group would be similar. The dosage of tamoxifen (ICI 46474) was either $10 \mathrm{mg}$ or $20 \mathrm{mg}$ twice daily.

During the first six months of treatment patients were seen at least monthly, and thereafter some were allowed a two-month interval between visits. At the beginning of the trial all patients had haematological and biochemical investigations at least every month but when normal results had been obtained regularly for six months the interval was lengthened.

Symptomatic Side Effects.-The incidence of symptoms attributable to the drug is shown in table $I$. When a patient had more than one symptom each has been noted so that the number of symptoms recorded exceeds the number of patients 
TABLE I-Incidence of Symptoms Resulting from Treatment with Tamoxifen $10 \mathrm{mg}$ Twice Daily $(L)$ or $20 \mathrm{mg}$ Twice Daily $(H)$

\begin{tabular}{|c|c|c|c|c|c|c|c|c|c|c|c|}
\hline & & \multicolumn{2}{|c|}{$\begin{array}{l}\text { Within five } \\
\text { Years of } \\
\text { Meno- } \\
\text { pause }\end{array}$} & \multicolumn{2}{|c|}{ Age 50-59 } & \multicolumn{2}{|c|}{ Age $60-69$} & \multicolumn{2}{|c|}{$\begin{array}{c}\text { Age } 70 \\
\text { or } \\
\text { Over }\end{array}$} & \multicolumn{2}{|c|}{ Total } \\
\hline & & $\mathbf{L}$ & $\mathbf{H}$ & $\mathbf{L}$ & $\mathbf{H}$ & L & $\mathbf{H}$ & $\mathbf{L}$ & $\mathbf{H}$ & $\mathbf{L}$ & $\mathbf{H}$ \\
\hline $\begin{array}{l}\text { Hot flushes } \\
\text { Nausea } \\
\text { Vomiting } \\
\text { Headache } \\
\text { Dizziness } \\
\text { Confusion } \\
\text { Lassitude } \\
\text { Leg cramps }\end{array}$ & $\begin{array}{l}. \\
\ldots \\
\ldots \\
\ldots \\
\ldots \\
.\end{array}$ & 1 & $\begin{array}{l}1 \\
1 \\
1\end{array}$ & $\begin{array}{l}1 \\
1 \\
1\end{array}$ & 1 & $\begin{array}{l}3 \\
1\end{array}$ & $\begin{array}{l}2 \\
1 \\
1\end{array}$ & $\begin{array}{l}1 \\
1 \\
1\end{array}$ & $\begin{array}{l}3 \\
1 \\
1 \\
1\end{array}$ & $\begin{array}{l}4 \\
3 \\
2 \\
2 \\
1 \\
0 \\
0 \\
0\end{array}$ & $\begin{array}{l}4 \\
4 \\
0 \\
3 \\
1 \\
1 \\
1 \\
1\end{array}$ \\
\hline No. of patients & . & 5 & 7 & 8 & 6 & 11 & 10 & 9 & 12 & 33 & 35 \\
\hline No. with sympto & oms & 1 & 2 & 3 & 1 & 3 & 2 & 3 & 4 & 10 & 9 \\
\hline
\end{tabular}

with symptoms. Symptoms have been noted only for the initial dosage assigned by the randomization table. To avoid confusion the effect of any change in dosage has not been included in the table. Nevertheless, it should be noted that one patient who changed from high to low dosage experienced relief of nausea while another experienced relief of headache. One patient stopped treatment with high dosage after nine months because of the onset of dizziness, another stopped after five months because of headache and confusion, and a third stopped after three months because of nausea. In all three cases symptoms ceased when treatment was stopped. One patient on low dosage stopped treatment because of vomiting, but she had recently recovered from hepatitis. Not one patient suffered from any degree of virilization and none showed evidence of fluid retention.

Objective Side Effects. - The haemoglobin levels in the treated patients fluctuated only slightly, and the lowest recorded value was $10.4 \mathrm{~g}$ per $100 \mathrm{ml}$. The white cell counts also fluctuated slightly, and the lowest recorded value was $1,900 / \mathrm{mm}^{3}$ but in this patient the value rose to 4,100 a fortnight later. There is no reason to suppose that the treatment had any effect on haemoglobin or white cell levels. In five patients there was a transient fall in the platelet count below $100,000 / \mathrm{mm}^{3}$ but the lowest recorded value was 56,000 . In two of these treatment was suspended for a fortnight, but in all instances the platelet counts rose again a fortnight later. In two patients bone marrow examination showed normal appearances, and it was concluded that platelets were being lost from the blood at a higher rate than normal. Serum calcium and phosphate remained within normal limits in all patients. In four the alkaline phosphatase levels were raised (in three it was raised before treatment started) but all these patients had bone metastases. The aspartate aminotransferase was raised in eight patients. In three this could be explained by the presence of liver metastases, and another had hepatitis. The remaining four patients had bone metastases but liver metastases were not detected although they may have been present.

Tumour Responses.-In table II the responses are grouped according to the changes in linear dimensions of the tumours resulting from treatment. A reduction in size is counted only if it was sustained beyond three months. Tumour responses have been grouped according to the ages of the patients. There was no difference in tumour response rates when patients were grouped according to the presence or absence of blood-borne metastases so these groups have not been tabulated. Out of the 26 patients who showed a reduction in tumour size to half or less, five had been in remission for over a year and another 10 had been in
TABLE II-Effect of Tamoxifen on Tumour Size at Three Months. Dosage $10 \mathrm{mg}(\mathrm{L})$ or $20 \mathrm{mg}(\mathrm{H})$ Twice Daily

\begin{tabular}{|c|c|c|c|c|c|c|c|c|c|}
\hline & & \multicolumn{2}{|c|}{ Larger } & \multicolumn{2}{|c|}{$\begin{array}{l}\text { No Change } \\
\text { or Re- } \\
\text { growth After } \\
\text { Becoming } \\
\text { Smaller }\end{array}$} & \multicolumn{2}{|c|}{$\begin{array}{c}\text { Size Re- } \\
\text { duced to } \\
\text { Between } \\
99 \% \text { and } \\
51 \%\end{array}$} & \multicolumn{2}{|c|}{$\begin{array}{c}\text { Size Re- } \\
\text { duced to } \\
\text { Between } \\
50 \% \text { and } \\
\text { Zero }\end{array}$} \\
\hline & & $\mathbf{L}$ & $\mathbf{H}$ & L & $\mathbf{H}$ & $\mathbf{L}$ & $\mathbf{H}$ & $\mathbf{L}$ & $\mathbf{H}$ \\
\hline $\begin{array}{l}\text { Within five years o } \\
\text { menopause } \\
\text { Age } 50-59 \quad \ldots \\
\text { Age } 60-69 \quad \ldots \\
\text { Age } 70 \text { or over }\end{array}$ & $\begin{array}{l}f \\
\cdots \\
\because \\
\cdots\end{array}$ & $\begin{array}{l}2 \\
4 \\
4 \\
3\end{array}$ & $\begin{array}{l}4 \\
1 \\
1 \\
2\end{array}$ & $\begin{array}{l}1 \\
2\end{array}$ & $\begin{array}{l}1 \\
1 \\
2 \\
2\end{array}$ & $\begin{array}{l}1 \\
4\end{array}$ & $\begin{array}{l}3 \\
3 \\
1\end{array}$ & $\begin{array}{l}2 \\
3 \\
5 \\
2\end{array}$ & $\begin{array}{l}2 \\
2 \\
4 \\
6\end{array}$ \\
\hline Total .. & . & $\begin{array}{l}13 / 33 \\
(40 \%)\end{array}$ & $\begin{array}{r}8 / 35 \\
(23 \%)\end{array}$ & $\begin{array}{l}3 / 33 \\
(9 \%)\end{array}$ & $\begin{array}{r}6 / 35 \\
(17 \%)\end{array}$ & $\begin{array}{r}5 / 33 \\
(15 \%) \\
\end{array}$ & $\begin{array}{r}7 / 35 \\
(20 \%)\end{array}$ & $\begin{array}{l}12 / 33 \\
(36 \%)\end{array}$ & $\begin{array}{l}14 / 35 \\
(40 \%)\end{array}$ \\
\hline
\end{tabular}

remission for over six months. Some tumour responses were as spectacular as those sometimes seen after hypophysectomy. Thus, in one patient widespread skin deposits disappeared, and in another a greatly enlarged hard liver became impalpable within three months of starting treatment. The trial was not designed to study the effect of the drug on bone metastases, but the clinical impression was that the drug was less effective for these than for soft tissue deposits.

\section{Discussion}

In the report of Cole et al. (1971) a definite response was noted in 10 out of 46 patients (22\%) treated with tamoxifen (ICI 46474) while a further $37 \%$ showed a partial response. A definite response was defined as reduction in tumour size to half or less lasting for at least three months (I. D. H. Todd, personal communication). The dose of tamoxifen was $10 \mathrm{mg}$ either once or twice daily.

In the present study 12 out of 33 patients (36\%) receiving $10 \mathrm{mg}$ of tamoxifen twice daily showed a definite response while a further $8(24 \%)$ showed a partial response. The difference in results may have been due to sampling errors or to the difference in dosage.

When patients received $20 \mathrm{mg}$ of tamoxifen twice daily a definite response was seen in 14 out of $35(40 \%)$ and a partial response in a further $13(37 \%)$.

If the figures for definite and partial responses are added together the total response rates are $60 \%$ for low dosage and $77 \%$ for high dosage.

There was no evidence that the drug had any effect on the bone marrow, liver function, or blood calcium levels. The incidence of symptomatic side effects was almost the same at either dose level, and the particular advantages of this drug were the absence of virilization or fluid retention and the fact that injections were not required.

I am grateful to Dr. R. T. Rouse for his help and to Imperial Chemical Industries Limited for supplying ICI 46474. Also I thank my colleagues in the radiotherapy department for their ${ }^{\text {h }}$ help in this trial.

\section{References}

Cole, M. P., Jones, C. T. A., and Todd, I. D. H. (1971). British fournal of Cancer, 25, 270.

Herbst, A. L., Griftiths, C. T., and Kistner, R. W. (1964). Cancer Chemotherapy Reports, 43, 39.

Kistner, R. W., and Smith, O. W. (1960). Surgical Forum, 10, 725. 